\title{
Biodiesel production through algal cultivation in urban wastewater using algal floway
}

\author{
Thomas Kiran Marella ${ }^{\mathrm{a}}$, Aviraj Datta ${ }^{\mathrm{a}}$, Mukund D. Patil ${ }^{\mathrm{a}}$, Sreenath Dixit ${ }^{\mathrm{a}}$, Archana Tiwari ${ }^{\mathrm{b}, *}$ \\ ${ }^{a}$ International Crop Research Institute for Semi-arid Tropics (ICRISAT), Patancheru 502 324, Telangana State, India \\ ${ }^{\mathrm{b}}$ Diatom Research Laboratory, Amity Institute of Biotechnology, Amity University, Noida, Uttar Pradesh 201 313, India
}

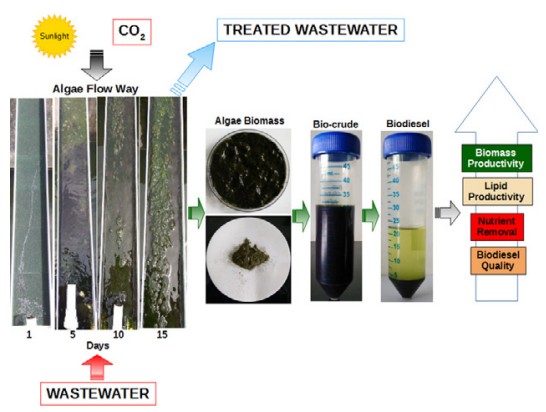

\section{A R T I C L E I N F O}

\section{Keywords:}

Algae floway

Biodiesel

Diatoms

Phycoremediation

Wastewater

\begin{abstract}
A B S T R A C T
The aim of this work was to study algal floway (AFW) to treat urban wastewater and to evaluate biomass productivity, lipid contents and biodiesel production. The results indicated the seasonal average algae productivity of $34.83 \mathrm{~g}$ dry weight $\mathrm{m}^{2} \mathrm{~d}^{-1}$ with a nutrient removal rate of $2.52 \mathrm{~g} \mathrm{~m}^{2} \mathrm{~d}^{-1} \mathrm{~N}$ and $1.25 \mathrm{~g} \mathrm{~m}^{2} \mathrm{~d}^{-1} \mathrm{P}$ while the lipid content ranged between 14 and $22 \%$ of dry cell weight with the highest lipid productivity of $9.29 \mathrm{~g} \mathrm{~m}^{-2} \mathrm{~d}^{-1}$ during summer. Biodiesel quality was superior during summer with high centane number and cold filter plugging point values. High eicosapentaenoic acid content was found during winter growth cycles. AFW algae community was dominated by pennate diatoms during all growing seasons. This study is one of its kinds in Indian wastewaters and it provides fundamental information for further optimization and use of AFW to treat domestic wastewater and to produce algae biofuel feedstock.
\end{abstract}

\section{Introduction}

Microalgae derived biofuels are known to be superior to land based crop derived fuels owing to several advantages. But there is an urgent need to develop methods to produce algae biomass inexpensively in bulk quantities to make this economically viable (Pate, 2013). Anthropogenic activities have contributed to increased cultural eutrophication in aquatic ecosystems. Due to the generation of large quantities of untreated domestic wastewater in urban and semi-urban areas, using this water as a source for nutrients for algae feedstock production is an attractive option to offset the biodiesel production costs (Craggs et al., 2011).

Algae culture technologies like raceway ponds and photobioreactors are in use for decades but they are expensive and energy intensive due to which net energy recovered from algae oil is high (Chisti, 2013). Method of cultivation plays a key role in how the biomass can be

\footnotetext{
* Corresponding author.

E-mail address: panarchana@gmail.com (A. Tiwari).
} 
harvested, using traditional bioreactors with suspended cultures the cost and energy consumption for harvesting increases which influence the cost of biodiesel produced (Adeniyi et al., 2018). So inexpensive and energy efficient technologies with high biomass productivity with efficient harvesting methods are the demand of the hour worldwide. Algae turf scrubber (ATS) is an algae based wastewater treatment system invented by Dr. Walter Adey (Adey and Loveland, 2007). ATS generated biomass can be used to produce biofuel but the majority of ATS research to date has looked at nutrient removal using different wastewater sources primarily from temperate regions of United States (Kangas et al., 2017). Use of wastewater such as urban wastewater for algal cultivation could offer potential benefits serving a dual purpose of treating the wastewater as well as producing lipids-rich biomass, which could be used for biodiesel production (Ubeda et al., 2017; Schulze et al., 2017). Wastewater provides macro and micronutrients essential for algae growth. Algae assimilate nutrients by biosorption and utilize it for its metabolic activities and store excess energy in the form of lipids, carbohydrates and proteins. Depending on algae type, culture method and nutrient stress algae are known to change their form of stored energy (Pinto et al., 2018). Both macro and microalgae biomass can be a potential feedstock for third generation biofuels (Tamilarasan et al., 2018). Algae feedstock generated from wastewater as a nutrient source contain the high amount of carbohydrates, proteins and lipids and thus can be utilized for enhanced biomethane production with anaerobic digestion (Ganesh Saratale et al., 2018). India is one of the eight countries where maximum annual average lipid yield between 24-27 $\mathrm{m}^{3} \mathrm{ha}^{-1} \mathrm{y}^{-1}$ with an algal biomass yield of $13-15 \mathrm{~g} \mathrm{~m}^{-2} \mathrm{~d}^{-1}$ can be achieved based on light and temperature availability required for algae production (Moody et al., 2014). As algae biomass and lipid productivity is influenced by environmental conditions such as sunlight and temperature, it would be interesting to carry out similar studies in tropical climatic zones for its widespread implementation.

In India at least $75 \%$ of domestic wastewater generated is not treated due to inadequate connectivity to treatment facilities and lack of adequate infrastructure for decentralized wastewater treatment systems leading to eutrophication (Williams et al., 2019). The primary objective of this study was to determine algae biomass productivity, lipid productivity and nutrient removal of a simple continuous flow, self-seeding algal flow-way system using urban untreated wastewater. In addition, we want to evaluate the suitability of AFW biomass as biodiesel feedstock by analyzing key fuel characters based on fatty acid methyl ester (FAME) profiles. This is the first step towards large scale application of AFW to improve water quality with simultaneous production of algae biofuels.

\section{Materials and methods}

\subsection{Site description}

AFW unit was located adjacent to a constructed wetland treating urban domestic wastewater (Tilak et al., 2017). The wastewater is from a non-point source originating from a residential colony. Wastewater from the inlet channel was pumped into a storage tank using a submersible pump.

\subsection{Algal floway operation and sampling}

A pilot scale algae flow way $0.75 \mathrm{~m}$ long, $0.1 \mathrm{~m}$ wide and $0.05 \mathrm{~m}$ depth; with a total growing area of $0.07 \mathrm{~m}^{2}$ with a slope of $1 \%$ was fabricated using aluminum. The growing area was lined with a polyester mat with a thickness of $10 \mathrm{~mm}$ as a substrate for periphyton growth. Wastewater from the storage tank was allowed to flow continuously on to the AFW by gravity flow through $10 \mathrm{~cm}$ PVC pipe at $65 \mathrm{Lmin}^{-1}$. A water flow meter was connected before the inlet to measure water flow. After the water was passed on to the AFW, it was allowed to flow into a concrete inlet tank of a constructed wetland thus creating a continuous flow way. Naturally occurring algae from the wastewater were allowed to self-seed and grow as periphyton on the substrate.

Three experiments were carried out in 2017-2018 covering three seasons (summer: April-May, rainy: August-September and winter: December-January). After each experiment, AFW was stopped and grown fresh during the next season. Each experiment was carried out in three cycles with duration of 15 days. Algae biomass was harvested at the end of each cycle after stopping the water flow for $30 \mathrm{~min}$ and allowing the water to drain. Substrates were removed manually and algae biomass was harvested into a plastic tray by scrapping the surface using a metal scraper. Harvested biomass was collected in wide- mouthed plastic container and transported to the laboratory for analysis in insulated container with ice and stored in $-20^{\circ} \mathrm{C}$ freezer until analysis. Water samples from inlet were collected every week manually in $500 \mathrm{ml}$ plastic bottles and transported to the laboratory immediately and stored at $-20^{\circ} \mathrm{C}$ until analysis. Environmental data on temperature, rainfall, photosynthetically active radiation (PAR) during the study period were collected from ICRISAT meteorology lab.

\subsection{Algae biomass and community analysis}

Harvested biomass was transferred into a plastic petri dish and oven dried (UNITHERM, Marlen, Missouri, USA) at $72^{\circ} \mathrm{C}$ overnight until it reached a constant weight. Dried biomass was pulverized using mortar and pestle and dry weight of the resulting powder was determined using an electronic balance (QUINTIX5102, Sartorius, Gottingen, Germany). The algae growth rate was calculated using the following equation

Algae growth rate $\left(\mathrm{g} \mathrm{m}^{2} \mathrm{~d}^{-1}\right)$
$=$ Dried weight $(\mathrm{g}) /$ ATS area $\left(\mathrm{m}^{2}\right) /$ Cultivation time $(\mathrm{d})$

A sub sample with Lugol's solution of fresh biomass was analyzed for live algae community analysis. Samples were analyzed under $400 \times$ and $1000 \times$ using Zeiss axio lab.A1 microscope (Carl Zeiss, Bangalore, India) with phase contrast in triplicate for each sample from different growth cycles during each season. For diatom analysis, a subset of fresh algae biomass was washed according to Hasle and Fryxell (1970). Diatom samples were mounted using naphrax high resolution diatom mountant with refractive index 1.73 (Brunel microscopes, Wiltshire, UK) onto glass slides for microscopic examination. Phytoplankton relative abundance was estimated using morphological characters using taxonomic guides for Cyanophyta (Komarek et al., 2014), Bacillariophyta (Cox, 1996; Krammer and Bertalot, 1991a) and diatoms image database of India (DIDI) (Pandey et al., 2016b).

\subsection{Nutrient analysis}

Dried algae biomass samples ( $\sim 20 \mathrm{mg}$ ) were directly analyzed for $\mathrm{N}$ and $\mathrm{P}$ content using San ++ autoanalyzer (SKALAR, Netherlands) in triplicate. Water samples were analyzed for total nitrogen (TP) and total phosphate (TP) using standard spectrometric methods (APHA, 1998).

\subsection{Lipid extraction and analysis}

One gram of dried algae biomass was used for total lipid extraction according to Bligh and Dyer method modified for algal lipids (Bligh and Dyer, 1959). All reagents and solvents were of chromatography grade obtained from Sigma-Aldrich (Bangalore, India). Total lipid dry cell weight (DCW) was estimated by gravimetric method. An aliquot of crude lipid extract $(100 \mathrm{mg}$ ) was converted to FAME according to $\mathrm{Li}$ et al. (2017). Briefly, lipid extract was evaporated to dryness under a gentle stream of nitrogen and re-dissolved in known volume of chloroform to this $\mathrm{NaOH}$ was added followed by $12 \% \mathrm{BF}_{3}$-methanol to convert fatty acids to respective methyl esters by acidic trans- 
Table 1

Inflow water quality and environmental conditions during experiment.

\begin{tabular}{|c|c|c|c|c|c|c|c|}
\hline Season & Temperature ${ }^{\circ} \mathrm{C}^{\mathrm{c}}$ & $\begin{array}{l}\text { Total rainfall } \\
(\mathrm{mm})\end{array}$ & $\begin{array}{l}\mathrm{PAR}^{\mathrm{c}} \\
\left(\mu \mathrm{mol} \mathrm{s}{ }^{-1} \mathrm{~m}^{-2}\right)\end{array}$ & $\begin{array}{l}\mathrm{TN}^{\mathrm{c}} \\
\left(\mathrm{mg} \mathrm{L}^{-1}\right)\end{array}$ & $\begin{array}{l}\mathrm{TP}^{\mathrm{c}} \\
\left(\mathrm{mg} \mathrm{L}^{-1}\right)\end{array}$ & $\begin{array}{l}\text { COD } \\
\left(\mathrm{mg} \mathrm{L}^{-1}\right)\end{array}$ & $\mathrm{pH}$ at $25^{\circ} \mathrm{C}$ \\
\hline Summer & $32.32 \pm 3.31^{\mathrm{a}}$ & 8.4 & $1147.31 \pm 94.1$ & $69.44 \pm 5.4$ & $3.7 \pm 0.6$ & $79.80 \pm 5.2$ & $8.75 \pm 0.7$ \\
\hline Rainy & $26.09 \pm 2.01$ & 220 & $781.87 \pm 71.2$ & $51.07 \pm 4.8$ & $3.8 \pm 0.2$ & $67.80 \pm 7.1$ & $8.03 \pm 0.8$ \\
\hline Winter & $20.54 \pm 2.12$ & $-\mathrm{b}$ & $825.42 \pm 68.7$ & $56.94 \pm 4.3$ & $4.4 \pm 0.5$ & $73.60 \pm 3.1$ & $8.12 \pm 0.3$ \\
\hline
\end{tabular}

a Values are \pm Standard deviation.

b No rainfall recorded during winter.

c Mean of entire growth period during particular season.

methylation. The resulting mixture was phase separated using $\mathrm{NaCl}$ and n-hexane and the resulting n-Hexane layer was used for fatty acid methyl ester (FAME) analysis.

FAME analysis was done using an Agilent 6890 gas chromatograph coupled with mass spectroscopy (Agilent 7673; Agilent Technologies, Palo Alto, CA, USA) using HP-5MS column $(30 \mathrm{~m} \times 0.25 \mathrm{~mm}$ i.d., $0.25 \mu \mathrm{m}$ film thickness) with $\mathrm{He}$ as the carrier gas and using conditions described in Suman et al. (2012). Fatty acid peaks were identified by comparing the retention times of authentic standards run under the same conditions and by comparing mass fragmentation patterns with Wiley library.

Lipid bodies (LBs) inside live diatom cells were analyzed according to Pandey et al. (2016a), Briefly, fresh periphyton sample was collected during initial (5th day) and final (15th day) stage of third growth cycle during each season was mixed with inlet water by vortexing and allowed to settle for $10 \mathrm{~min}$. A small aliquot $(20 \mu \mathrm{l})$ of the sample from bottom layer which consists of diatoms was put on to a hemocytometer and LBs inside diatom cells were analyzed through a microscope $(450 \times$ $\&(000 \times)$ with an attached camera. The number and volume of LBs were determined in at least ten cells of the most dominant taxon. The volume of LBs was estimated by considering them as spheres. LBs diameter was calculated microscopically and the volume of each LBs was calculated by using the value of radius (r) in the formula for sphere; i.e., $\mathrm{V}=4 / 3 \pi \mathrm{r} 3$, where $\mathrm{V}$ is the volume of a sphere and ' $r$ ' is the radius of the LBs. The total relative abundance of LBs inside each diatom cells was determined by adding the biovolume of each LBs divided by the biovolume of the frustules.

Biodiesel properties like cetane number (CN), saponification value (SV), iodine value (IV), degree of unsaturation (DU), long chain saturated factor (LCSF), cold filter plugging point (CFPP) and cloud point (CP) were calculated from FAME profile using empirical Eqs. (1)-(7) shown below (Talebi et al., 2013).

$\mathrm{CN}=46: 3+(5: 458 / \mathrm{SV})-(0: 225 \times \mathrm{IV})$

SV and IV were calculated from Eqs. (2) and (3), where $\mathrm{N}$ is the percentage of each fatty acid in FAME fraction, $\mathrm{M}$ is the molecular mass of each fatty acid and DN is percentage of unsaturated fatty acids.

$\mathrm{SV}=\Sigma(560 \times \mathrm{N}) / \mathrm{M}$

$\mathrm{IV}=\Sigma(254 \times \mathrm{DN}) / \mathrm{M}$

The degree of unsaturation (DU) was calculated based on Eq. (4), from monounsaturated (MUFA) and polyunsaturated fatty acid (PUFA) content of FAME.

$\mathrm{DU}=\mathrm{MUFA}+(2 \times \mathrm{PUFA})$

Three factors related to cold flow properties of biodiesel LCSF, CFPP and $\mathrm{CP}$ were calculated using Eqs. (5)-(7)

$\mathrm{LCSF}=(0.1 \times \mathrm{C} 16)+(0.5 \times \mathrm{C} 18)+(1 \times \mathrm{C} 20)$

$\mathrm{CRPP}=(3.147 \times \mathrm{LCSF})--16.477$

$\mathrm{CP}=(0.526 \times \mathrm{C} 16)--4.992$

\subsection{Statistical analysis}

The growth, nutrient removal and lipid productivity rates used for statistical analyses were the means \pm standard deviation (SD). All statistical analyses were carried out using SPSS version 21.0 software (SPSS Inc., Chicago, IL, USA). A one-way analysis of variance was used to compare the significance levels of variations in the mean between groups. Statistical values of $\mathrm{P}<0.05$ were considered significant rejecting the null hypothesis between groups.

\section{Results and discussion}

\subsection{Site characterization and algae productivity}

The primary source of wastewater for the AFW was domestic sewage from an upstream site with around 200 households. The water passed through an open channel with some wetland plants acting as a natural filter. Seasonal changes in inlet waters physicochemical parameters are shown in Table 1 . The average seasonal high and low ambient air temperatures for this study period were $39.7^{\circ} \mathrm{C}$ and $24.4^{\circ} \mathrm{C}$ during summer, $30.0^{\circ} \mathrm{C}$ and $22.2{ }^{\circ} \mathrm{C}$ during rainy and $22.30{ }^{\circ} \mathrm{C}$ and $11.8^{\circ} \mathrm{C}$ during winter, respectively. Average seasonal highest rainfall was observed during the month of August $(256.8 \mathrm{~mm})$. TN concentration in the inlet water generally ranged from $44.62 \mathrm{mg} \mathrm{l}^{-1}-69.44 \mathrm{mg} \mathrm{L}^{-1}$ in summer, $48.49 \mathrm{mg} \mathrm{L}^{-1}-53.46 \mathrm{mg} \mathrm{L}^{-1}$ in rainy and $48.38 \mathrm{mg} \mathrm{L}^{-1}-57.36 \mathrm{mg} \mathrm{L}^{-1}$ in winter. TP was higher ( $4.4 \mathrm{mg}^{-1}$ ) during winter. Summer season light intensity measured as PAR was higher compared to other seasons (Table 1). Domestic wastewater contains a high concentration of nitrogen, phosphorus and trace metals which can act as an inexpensive source of nutrients for microalgae cultivation (Li et al., 2011).

AFW biomass production varied seasonally with the highest production during summer (April-may) growth period. Total production ranged between 29.7 and $48.9 \mathrm{~g} \mathrm{~m}^{-2} \mathrm{~d}^{-1}$ with a mean of $42.2 \mathrm{~g} \mathrm{~m}^{-2} \mathrm{~d}^{-1}$ during summer, $14.29-36.9 \mathrm{~g} \mathrm{~m}^{-2} \mathrm{~d}^{-1}$ during rainy and $18.2-37.1 \mathrm{~g} \mathrm{~m}^{-2} \mathrm{~d}^{-1}$ during winter (Fig. 1.). Seasonal variation with the highest productivity during summer can be due to higher light availability (1147 $\left.\mu \mathrm{mol} \mathrm{s}^{-1} \mathrm{~m}^{-2}\right)$ and $\mathrm{N}$ and P loading (Table1). Previous studies using algae biofilm for wastewater treatment was done in temperate climates with low light and temperature, due to which those results cannot be a proper comparison to the present study, but Chen et al. (2015) working with river water from tropical region in china reported an algae productivity of $21.47 \mathrm{~g} \mathrm{~m}^{-2} \mathrm{~d}^{-1}$ with a low $\mathrm{N}$ and $\mathrm{P}$ loading which is similar with the results reported in the present study. Algae due to their fast growth rate are able to remove excess nutrients from wastewater in energy efficient and cost- effective manner with less land and carbon footprint (Liu and Vyverman, 2015). The growth rates achieved in the present work was similar to Craggs et al. (1996a) using sewage treatment plant secondary effluent $\left(35 \mathrm{~g} \mathrm{~m}^{-2} \mathrm{~d}^{-1}\right)$. Along with seasonal variation, we have observed a slight difference in biomass production between each growth cycle with mean biomass production of $20.75 \mathrm{~g} \mathrm{~m}^{-2} \mathrm{~d}^{-1}, 39.94 \mathrm{~g} \mathrm{~m}^{-2} \mathrm{~d}^{-1}$ and $38.9 \mathrm{~g} \mathrm{~m}^{-2} \mathrm{~d}^{-1}$ during first, second and third growth cycles, respectively. This might be due to time taken for natural seeding of algae periphyton community during initial 


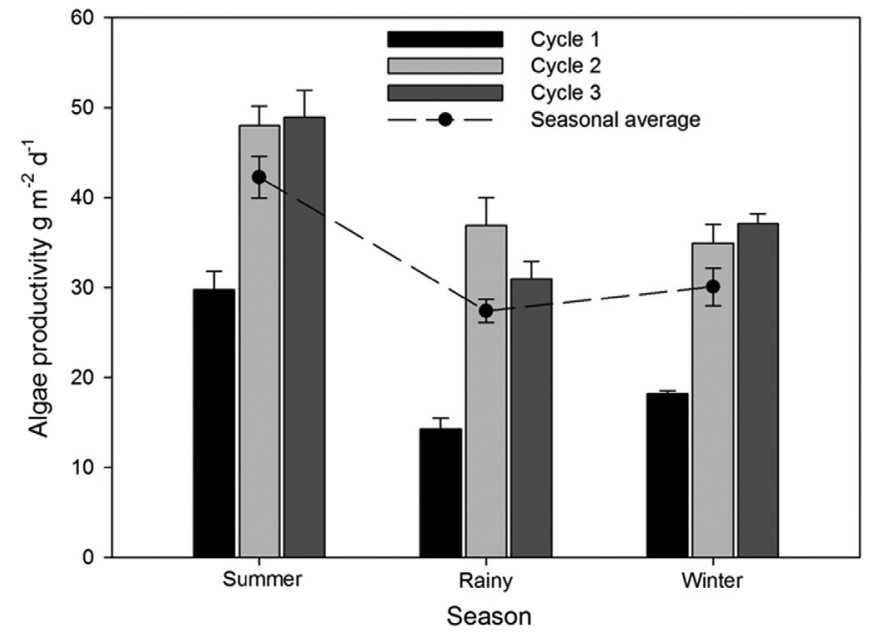

Fig. 1. Seasonal changes in algae productivity during three growth cycles with seasonal average. Error bars indicate \pm SD.

cycle and availability of higher number of logarithmic phase cells retained in mucilage and as hold fast cells even after harvesting which might have resulted in higher growth rate (Kangas et al., 2017). During 3rd growth cycle in the rainy season, there was a slight decrease in production which is against the trend this was due to loss of biomass due to heavy rains which dislodged some periphyton from substrate. AFW contains consortia of phototrophs (algae) and Chemotrophs (bacteria and fungi) which are known to have symbiotic relation this makes biofilm dynamic in terms of mechanical stability, creating conducive environments for better cell growth and metabolism leading to higher growth rate and nutrient removal (Gismondi et al., 2016). Conventional algae-bacterial systems in bioreactors need constant aeration or agitation to create a bio-floc which enhances the synergy between both organisms which is energy intensive. In AFW interaction between algae and bacteria is enhanced due to shallow water depth, constant water flow, proximity to each other and oxygen availability to aerobic organisms through algal photosynthesis. Harvesting cost is one of the major drawbacks for commercialization of algae biofuels, algae biomass produced with AFW was grown as a compact biofilm which can be easily scrapped manually or mechanically siphoned off using a dry suction pump, and this will reduce the cost of harvesting.

\subsection{Algae community analysis}

A natural assembly of microalgae developed as a biofilm on the AFW. Species composition was studied by analyzing different species present in the periphyton. Species composition varied slightly during growth season but there was no significant difference between different growth cycles. Algae consortia was dominated by benthic pennate diatoms including Nitzscia palea, Nitzschia umbanota, Nitzschia amphibia, Nitzschia lanceolata, Gomphonema parvulum, Centric diatoms Cyclotella meninghiana and chain forming Melosira varians along with other small unknown pennate diatoms. Dominant diatoms found in this study were known to be pollution tolerant species (Delgado et al., 2012). During the initial growth phase, filamentous cyanobacteria (Oscillatoria sp. and Phormidium sp.) were observed which acted as a canopy of the biofilm onto which benthic diatoms were attaching to form a layer. During rainy and winter season filamentous green algae was prevalent during the initial phase which was quickly replaced by diatoms. Higher light and $\mathrm{N}$ and $\mathrm{P}$ loading rate resulted in filamentous cyanobacteria and diatom dominance during summer whereas low light and temperature during rainy and winter reason triggered filamentous green algae (Spirogyra) and diatom growth. Similar biofilm characters were observed by Kangas et al. (2017) while treating river water using algae turf scrubbers but with slight change in species diversity with decreased

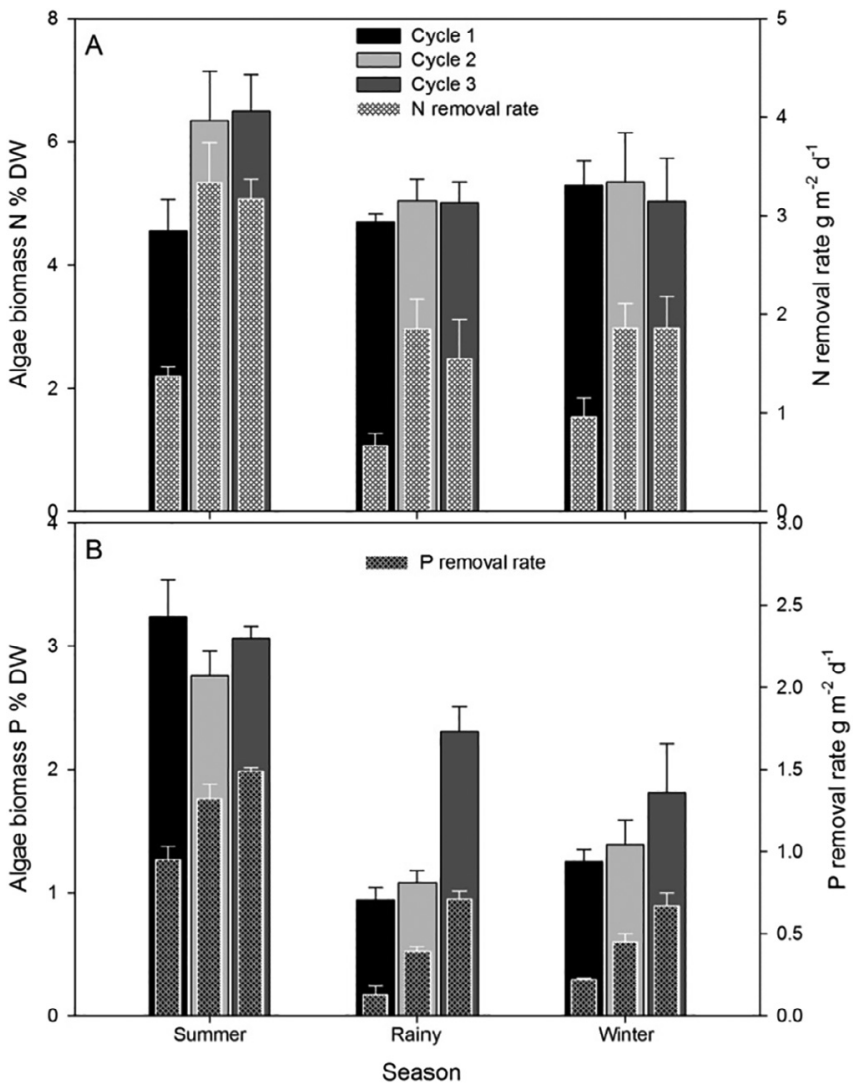

Fig. 2. $N(A)$ and $P(B)$ percentage and nutrient removal rate of AFW biomass. Error bars indicated \pm SD.

cyanobacterial diversity and increased diatom diversity. Diatom algae are highly diverse and known to inhabit various types of polluted waters. Due to their tolerance and sensitivity to changes in water quality they also act as efficient bio-indicators for water quality. Diatoms produce extracellular polysaccharides (EPS) which is utilized by chemotrophs in turn they provide vitamins essential for diatom growth creating a efficient symbiotic relationship which is critical for bioremediation of wastewater (Gugi et al., 2015). Diatoms algae are most dominant periphyton community in non-point source AFW (Adey et al., 2013), algae diversity analysis from the present work supported this observation.

\subsection{Nutrient removal rate}

Harvested biomass form AFW was analyzed for the elemental composition to calculate nutrient removal rate. Based on biomass productivity and nutrient content nutrient removal rate was calculated (Fig. 2). Mean seasonal removal rate of $\mathrm{N}$ was 2.52, 1.35 and $1.56 \mathrm{~g} \mathrm{~m}^{-2} \mathrm{~d}^{-1}$ and $\mathrm{P}$ was $1.25,0.41$ and $0.44 \mathrm{~g} \mathrm{~m}^{-2} \mathrm{~d}^{-1}$ during summer, rainy and winter, respectively. Seasonal variation in harvested biomass $\mathrm{N}$ and $\mathrm{P} \%$ and removal rate was shown in the Fig. $2 \mathrm{~A}$ and $\mathrm{B} . \mathrm{N}$ and $\mathrm{P} \%$ of harvested biomass ranged from $5.01-6.49 \%$ to $0.94-3.24 \%$ (by weight), respectively. $\mathrm{N}$ and $\mathrm{P}$ content of biomass was high during summer $(5.79 \% \mathrm{~N}$ and $3.02 \% \mathrm{P})$, this might be due to the high nutrient loading rate. But earlier studies with swine manure water with high $\mathrm{N}$ and $\mathrm{P}$ loading (1400 $\mathrm{N} \mathrm{mg} \mathrm{L}^{-1} ; 420 \mathrm{P} \mathrm{mg} \mathrm{L}^{-1}$ ) resulted in low nutrient $\%$ and removal rate (Kebede-Westhead et al., 2006). Higher nutrient loading might not be only factor for algae productivity, but fewer fluctuations in light and temperature during all three growth cycles might have contributed to increased growth and nutrient removal in the present study. Nutrient \% values from this study is similar to the values reported by Mulbry et al. (2008) using diluted dairy 


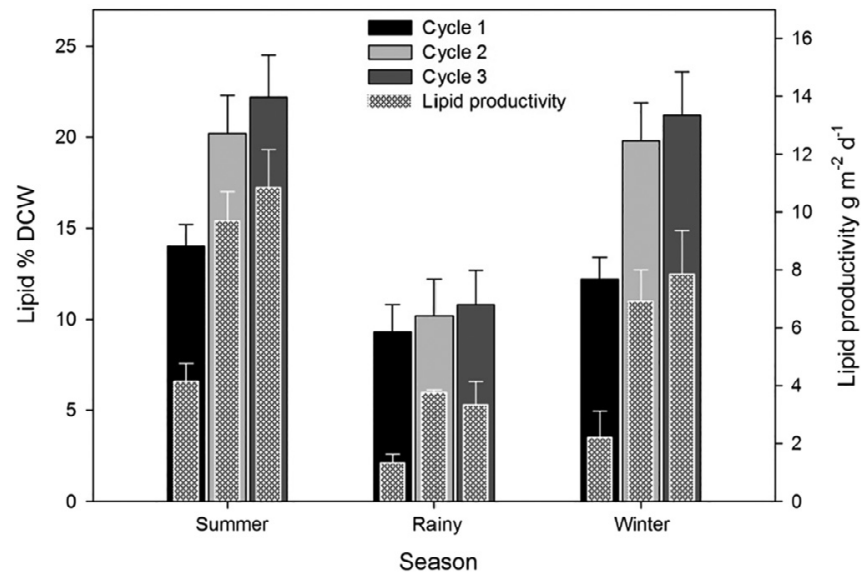

Fig. 3. Total lipid content and lipid productivity of AFW biomass. Error bars indicate \pm SD.

manure $(5.9 \% \mathrm{~N}$ and $0.8 \% \mathrm{P})$ but in a similar study using treated sewage which is more comparable to the effluent used in the present study the nutrient $\%$ is significantly less $(3.1 \% \mathrm{~N}$ and $2.1 \% \mathrm{P}$ ) (Craggs et al., 1996b). Changes in $\mathrm{N}$ and $\mathrm{P}$ content of harvested biomass can be due to slight changes in algal diversity, the innate ability of algae to utilize particular nutrients under varying physicochemical conditions and seasonal changes in effluent nutrient concentration which was a result of changes in water use patterns at the wastewater source. Nutrient removal rate and algal productivity are indicators of AFW performance. Nutrient removal rate was directly influenced by algal productivity and biomass nutrient content.

\subsection{Lipid studies}

\subsubsection{Lipid content}

Total lipid DCW \% of the harvested biomass ranged between $(9.3-22.2 \%)$ during three seasons. Highest of $22.2 \%$ DCW was achieved during 3rd growth cycle in summer. During rainy season lowest lipid content which ranged from $9.3 \%$ to $10.8 \%$ was observed. There was a gradual increase in lipid content with growth cycle during all seasons studied (Fig. 3). Diatom algae are known to produce high amount of total lipids compared to cyanobacteria and filamentous green algae (Hu et al., 2008). Presence of cyanobacteria during summer and filamentous green algae during rainy and winter initial growth cycle which are quickly dominated by diatoms might be the reason for lower lipid content during the initial growth cycle. Lipid productivity reached up to $10.8 \mathrm{~g} \mathrm{~m}^{-2} \mathrm{~d}^{-1}$ in summer, $3.76 \mathrm{~g} \mathrm{~m}^{-2} \mathrm{~d}^{-1}$ in rainy and $7.86 \mathrm{~g} \mathrm{~m}^{-2} \mathrm{~d}^{-2}$ in winter. Total lipid \% reported in the present work is significantly higher than previous reports, which ranged from $0.35 \%$ to $2 \%$ using recirculating (Mulbry et al., 2008a) and single pass AFW (Mulbry et al., 2010). Nutrient limitation is a known factor which triggers higher lipid accumulation but in this study with continuous loading of nutrients, there is no nutrients deplete condition. Prior to this study, FA content and FAME profiles of ATS biomass grown using untreated domestic wastewater was not reported. A single pass system with diatom domination could lead to high lipid content, this hypothesis was tested earlier by Mulbry et al. (2010) using natural waters. But their results did not support this hypothesis, in the present study using high nutrient wastewater under elevated temperature and light availability AFW biomass with diatoms as the most dominant algae present in the periphyton during all growth cycles across seasons contained high lipid content.

Algae produce lipids as a storage form of energy. Lipid bodies (LBs) are produced under different stress conditions like nutrient depletion, high light, metal contamination etc. (d'Ippolito et al., 2015; Lin et al., 2018). In the present study, we made an effort to study the number of LBs and their size in most commonly occurring diatoms species during initial and final growth phases using microscopic analysis (Table 2). Reason to select diatoms for this analysis was due to their high dominance ( $>80 \%$ relative abundance) during all three growth cycles and easy visualization of LBs in live cells under the microscope. During the initial growth phase number of LBs raged from 0 to 2 in all the species studied except in Nitzschia palea (0-2), their number increase threefold and reached 2-8 in final growth phase. Higher lipid LBs diameter was observed in Gomphonema parvulum (0.5-3.1 $\mu \mathrm{m})$ and Navicula lanceolata $(0.5-3.2 \mu \mathrm{m})$. The contribution of lipid bodies to cell bio volume was up to $60 \%$ in Nitzschia amphibia and Nitzschia umbanota, the reason could be due to their small cell size and high LBs number. A marked elevation in lipid body number and size was observed in final growth phase resulting in higher lipid \% DCW. Domestic wastewater used in the present study contains trace concentrations of heavy metals (not shown), this might have influenced increased lipid accumulation as algae are known to adsorb and absorb heavy metals and biofilms can bio-magnify resulting in higher concentration in the periphyton. Elevated lipid accumulation in response to metal stress was used as an important biomarker in bio-assessment studies (Pandey et al., 2015) but in the present study, we used the same methodology to estimate lipid enhancement for biofuel production. Although we are able to positively correlate an increase in lipid production through this technique further research is required to substantiate this method.

\subsubsection{FAME profiling}

Fatty acid profiles of lipid from harvested biomass were tabulated in Table 3. Three most commonly occurring FA of microalgae C16:0, C16:1 and C18:0 were major fatty acids present with slight seasonal variation. EPA which is major poly unsaturated fatty acid (PUFA) present in diatoms was present as a major fatty acid component in the range of $6.2-24.8 \%$. During 3rd growth cycle in winter EPA was the major fatty acid due to total dominance of diatoms. Most commonly occurring fatty acids in microalgae have chain length range from C16 to C18 which is in accordance with the present study (Cobelas and Lechado, 1989). Temperature and light are known to influence fatty acid unsaturation. Under high light and temperature algae tends to

Table 2

Lipid body characteristics of six commonly occurring diatom species of AFW periphyton.

\begin{tabular}{|c|c|c|c|c|c|c|}
\hline & \multicolumn{2}{|c|}{ No of lipid bodies } & \multicolumn{2}{|c|}{ Diameter of lipid bodies $(\mu \mathrm{m})$} & \multicolumn{2}{|c|}{$\%$ contribution of lipid bodies to total cell biovolume } \\
\hline Gomphonema parvulum & $0-2^{\mathrm{a}}$ & $2-6$ & $0.0-0.4$ & $0.5-3.1$ & $2-7$ & $10-30$ \\
\hline Nitzshia amphibia & $0-2$ & $2-6$ & $0.0-0.2$ & $0.2-2.0$ & $4-9$ & $20-60$ \\
\hline Nitzschia palea & $0-4$ & $4-8$ & $0.0-0.3$ & $0.4-1.8$ & $1-5$ & $11-30$ \\
\hline Nitzschia umbanota & $0-2$ & $2-6$ & $0.0-0.3$ & $0.3-1.3$ & $4-7$ & $15-60$ \\
\hline
\end{tabular}

\footnotetext{
${ }^{\text {a }}$ Values given are average of three seasons.

b Initial and final growth phase represent 5th and 15th day respectively of third growth cycle.
} 
Table 3

Seasonal variation in fatty acid composition of AFW biomass.

\begin{tabular}{|c|c|c|c|c|c|c|c|c|c|}
\hline \multirow{2}{*}{$\begin{array}{l}\text { Fatty acid } \\
\text { Cycle }\end{array}$} & \multicolumn{3}{|c|}{ Summer } & \multicolumn{3}{|c|}{ Rainy } & \multicolumn{3}{|c|}{ Winter } \\
\hline & 1 & 2 & 3 & 1 & 2 & 3 & 1 & 2 & 3 \\
\hline C14:0 & 5.2 & 3.2 & 3.3 & 3.7 & 3.6 & 2.5 & 1.3 & 0.6 & 0.7 \\
\hline $\mathrm{C} 14: 1(n-5)$ & 2 & 1.9 & 3.2 & 2.1 & 2 & 1.7 & 2.9 & 2.3 & 3 \\
\hline C15:0 & 0.2 & 0.2 & $--^{\mathrm{a}}$ & 0.2 & - & 0.3 & 0.1 & - & 0.2 \\
\hline C16:0 & 26.2 & 28.5 & 25.2 & 20.2 & 20.1 & 17.1 & 20.2 & 13.7 & 11.1 \\
\hline $\mathrm{C} 16: 1(n-7)$ & 21.3 & 22.5 & 19.7 & 25.2 & 19.2 & 22.3 & 25.3 & 31.2 & 22.2 \\
\hline C17:0 & 2.4 & 1.1 & 2.3 & 1.2 & 1.2 & 1.4 & - & 0.5 & 1.2 \\
\hline C18:0 & 16.1 & 15.2 & 13.3 & 11.2 & 9.3 & 9.2 & 8.5 & 10.2 & 7.2 \\
\hline C18:1 & 15.3 & 14.2 & 13.8 & 13 & 17.8 & 17.3 & 18.4 & 13.3 & 17.1 \\
\hline C18:2(n-6) & - & 1.8 & 9.2 & 1.2 & 4.2 & 2.1 & 2.4 & 3.3 & 3.7 \\
\hline $\mathrm{C} 18: 3(n-6)$ & 1.6 & 2.1 & 1.3 & 2.1 & 2.1 & 3.7 & 2.1 & - & 3.5 \\
\hline C20:0 & 1.9 & 1.7 & 1.2 & 1.2 & 1.2 & - & 1.1 & 1.1 & 1.3 \\
\hline $\mathrm{C} 20: 4(n-6)$ & 0.5 & 1 & 1.2 & 1.9 & 1.3 & 2.49 & 2.1 & 1.5 & 2.8 \\
\hline $\mathrm{C} 20: 5(n-3)$ & 7.1 & 6.5 & 6.2 & 15.7 & 17.2 & 19.1 & 14.7 & 21.2 & 24.8 \\
\hline C20:6(n-3) & 0.2 & 0.1 & 0.1 & 1.1 & 0.8 & 0.81 & 0.9 & 1.1 & 1.2 \\
\hline SFA & 52 & 49.9 & 45.3 & 37.7 & 35.4 & 30.5 & 31.2 & 26.1 & 21.7 \\
\hline MUFA & 38.6 & 38.6 & 36.7 & 40.3 & 39 & 41.3 & 46.6 & 46.8 & 42.3 \\
\hline PUFA & 9.4 & 9.7 & 8.8 & 20.8 & 21.4 & 26.1 & 19.8 & 23.8 & 32.3 \\
\hline
\end{tabular}

a Not detected.

produce saturated fatty acid (SFA) more and lower light and temperature can trigger the accumulation of MUFA and PUFA (Hu et al., 2008). In the present study, we observed the same trend with an increase in SFA content during summer (49\%), whereas mono unsaturated fatty acid (MUFA) (45.2\%) and PUFA (25.3\%) content was higher during winter.

\subsubsection{Biodiesel quality}

Lipid quality is an important factor in biodiesel production. To estimate the quality of biodiesel produced using AFW biomass in meeting international fuel standards, biodiesel quality parameters were calculated from FAME profiles and tabulated in Table 4. DU is an important factor which influences the storage of biodiesel through which we can also estimate another key parameter IV. CN which governs fuel combustion quality was calculated from IV and SV. SV (mg of KOH required to saponify $1 \mathrm{~g}$ of oil) differed very slightly between seasons with a combined seasonal average of 207.09. IV was high during winter (64.0-71.62). Higher cetane number which can result in shorter ignition delay was attained with biodiesel produced during summer (36.1). Microalgae biodiesel DU value is high due to the presence of MUFA and PUFA in high amounts which can result in higher oxidation of biodiesel (Schenk et al., 2008). In present work due to the presence of high PUFA content biodiesel produced during winter showed higher seasonal average DU value (95.8), whereas in summer it is comparatively lower (56.5). Although ideal biodiesel prefer low levels of PUFA, this drawback can be rectified through partial catalytic hydrogenation. EPA and DHA can also be explored for pharmaceutical and neutraceutical purposes (Chisti, 2007).
LCSF indicates about the saturation of $\mathrm{H}$ atoms on to a carbon chain in FA which is correlated to CN and CFPP. In the present study highest LCSF values were observed during summer in the range of 20.74-24.97 and during winter they are at their lowest range (11.84-14.75). CFPP is the temperature at which fuel starts to crystalize blocking fuel filters of engines. Lowest CFPP value of $20.7^{\circ} \mathrm{C}$ was observed during winter and highest value of $61.9^{\circ} \mathrm{C}$ during summer. Higher unsaturation results in lower melting point so the biofuel produced in this study during winter is more suitable during low winter temperatures whereas biodiesel from summer with high CFPP can be ideal for summer use or a blend of summer and winter biodiesels may lead to biodiesel with improved CFPP and DU values which are closer to an ideal quality fuel. CP is defined as the temperature at which biodiesel starts to solidify which is one of the key criteria to judge biodiesel quality, in the present study highest and lowest $\mathrm{CP}$ value of $9.01{ }^{\circ} \mathrm{C}$ and $2.89^{\circ} \mathrm{C}$ was found during summer and winter growth periods, respectively. Biodiesel quality of mixed algae consortia was not reported earlier but values reported earlier using single celled species of diatoms and green algae are similar to the values obtained from the present study (Talebi et al., 2013).

\subsection{Application potential and feasibility}

Nutrient removal rate and algal productivity both were higher than reported studies from temperate climatic regions like the US using treated and untreated wastewater and from subtropical areas like China using river water (Chen et al., 2015). The reason for this can be due to higher nutrient load from untreated sewage, high light availability because of tropical climate and less fluctuation in temperature in between seasons due to semi-arid conditions in the study area. Presence of high density of diatoms in the periphyton might also contribute to higher productivity as diatoms are known for faster growth rate, efficient nutrient assimilation and storage combined with tolerance to high heavy metal concentration and turbulence due to water flow (Hildebrand et al., 2012). The ability of the biofilm to maintain its mechanical stability and nutrient removal capacity depends on its periphyton community structure. In the present study periphyton community was dominated by colony forming pennate diatoms which are known to produce adhesive substances which helps them to adhere to solid support and form dense biofilms which can sustain high flowrates which results in higher nutrient assimilation. In large scale algae cultivation contamination of culture by invasive local algal strains and predation from zooplankton is a main issue. Growing mixed algae consortium as biofilm which are adapted to local physicochemical conditions can be advantageous but maintaining consistent lipid and functional ingredient productivity needs further optimization.

Algae's ability to utilize excess nutrients and metals from wastewaters for its growth and subsequent production of lipids and pigments was well documented. But to harness their potential for third generation biofuel production with simultaneous wastewater treatment, scalable cost effective and energy efficient growth and harvesting technologies are needed. With AFW we can grow algae as biofilm on a

Table 4

Biodiesel properties of AFW biodiesel.

\begin{tabular}{|c|c|c|c|c|c|c|c|c|c|}
\hline \multirow[b]{3}{*}{ Biodiesel parameter } & \multicolumn{3}{|c|}{ Summer } & \multicolumn{3}{|l|}{ Rainy } & \multicolumn{3}{|l|}{ Winter } \\
\hline & \multicolumn{9}{|c|}{ Growth cycle } \\
\hline & 1 & 2 & 3 & 1 & 2 & 3 & 1 & 2 & 3 \\
\hline $\mathrm{CN}$ & 36.27 & 35.82 & 36.38 & 33.90 & 33.11 & 32.10 & 32.06 & 31.01 & 30.34 \\
\hline SV & 210.31 & 206.99 & 209.70 & 207.99 & 206.49 & 205.84 & 207.33 & 205.84 & 203.30 \\
\hline IV & 45.27 & 47.28 & 44.77 & 55.82 & 59.34 & 63.80 & 64.00 & 68.65 & 71.62 \\
\hline DU & 57.40 & 58.00 & 54.30 & 81.90 & 81.80 & 93.50 & 86.20 & 94.40 & 106.90 \\
\hline LCSF & 24.97 & 21.18 & 20.74 & 17.59 & 15.69 & 12.79 & 14.75 & 15.00 & 11.84 \\
\hline CFPP & 61.98 & 50.08 & 48.69 & 38.77 & 32.83 & 23.70 & 29.86 & 30.66 & 20.72 \\
\hline $\mathrm{CP}$ & 8.79 & 10.00 & 8.26 & 5.63 & 5.58 & 4.00 & 5.63 & 2.21 & 0.85 \\
\hline
\end{tabular}


platform which can be fabricated with cost- efficient, ecofriendly locally available durable materials. Depending on the material, platforms can be stacked vertically instead of horizontally which can save land area especially in urban areas where the availability of land for wastewater treatment plants is scarce. Energy consumption for pumping of wastewater to the top of the stacked platforms can be achieved by solar pumps. Harvesting cost is one of the major drawbacks hindering commercialization of algae biofuels (Chisti, 2013). Growing algae as a biofilm instead of suspension cultures can be an alternative as instead of energy intensive centrifugation we can harvest manually or mechanically with minimum energy consumption. Future experiments are planned to scale up stackable AFW as an option for decentralized wastewater treatment with simultaneous generation of biodiesel feedstock in urban and peri-urban areas.

\section{Conclusions}

This is the first report on the use of AFW to treat untreated wastewater from India. Ability to control high lipid producing algae such as diatoms on the AFW is important for biodiesel feedstock. As evident from the results, diatom dominated community ( $>90 \%$ ) was well sustained. During summer, high biomass productivity and a low degree of unsaturation were observed which was ideal for biodiesel production. Elaborative and extensive investigations could help in elucidating the AFW technology as a viable, effective and amicable approach to wastewater treatment coupled with biofuel production thereby resolving global pollution issues.

\section{Acknowledgements}

Authors wish to thank Dr. S. P. Wani for encouragement and support. The authors would like to thank Hariom Singh for helping to run the AFW and Santhosh Kumar for nutrient analysis. Dr. Archana Tiwari is thankful to the Department of Biotechnology, Ministry of Science and Technology, India for research funding (BT/PR15650/AAQ/3/815/ 2016).

\section{References}

Adeniyi, O.M., Azimov, U., Burluka, A., 2018. Algae biofuel: current status and future applications. Renew. Sustain. Energy Rev. 90, 316-335.

Adey, W.H., Laughinghouse, H.D., Miller, J.B., Hayek, L.A.C., Thompson, J.G., Bertman, S., Hampel, K., Puvanendran, S., 2013. Algal turf scrubber (ATS) floways on the Great Wicomico River, Chesapeake Bay: productivity, algal community structure, substrate and chemistry. J. Phycol. 49, 489-501.

Adey, W.H., Loveland, K., 2007. Dynamic Aquaria: Building and Restoring Living Ecosystems. Academic Press.

APHA, 1998. Standard methods for examination of water and wastewater.

Bligh, E.G., Dyer, W.J., 1959. A rapid method of total lipid extraction and purification. Can. J. Biochem. Physiol. 37, 911-917.

Chen, N., Li, J., Wu, Y., Kangas, P.C., Huang, B., Yu, C., Chen, Z., 2015. Nutrient removal at a drinking water reservoir in China with an algal floway. Ecol. Eng. 84, 506-514.

Chisti, Y., 2013. Constraints to commercialization of algal fuels. J. Biotechnol. 167, 201-214.

Chisti, Y., 2007. Biodiesel from microalgae. Biotechnol. Adv. 25, 294-306.

Cobelas, M.A., Lechado, J.Z., 1989. Lipids in microalgae. A review. I. Biochemistry. Grasas Aceites 40, 118-145.

Cox, E.J., 1996. Identification of Freshwater Diatoms from Live Material Chapman \& Hall.

Craggs, R.J., Adey, W.H., Jenson, K.R., St. John, M.S., Green, F.B., Oswald, W.J., 1996a. Phosphorus removal from wastewater using an algal turf scrubber. Water Sci. Technol. 33, 191-198.

Craggs, R.J., Adey, W.H., Jessup, B.K., Oswald, W.J., 1996b. A controlled stream mesocosm for tertiary treatment of sewage. Ecol. Eng. 6, 149-169.

Craggs, R.J., Heubeck, S., Lundquist, T.J., Benemann, J.R., 2011. Algal biofuels from wastewater treatment high rate algal ponds. Water Sci. Technol. 63, 660-665.

d’Ippolito, G., Sardo, A., Paris, D., Vella, F., Adelfi, M., Botte, P., Gallo, C., Fontana, A., 2015. Potential of lipid metabolism in marine diatoms for biofuel production. Biotechnol. Biofuels 8, 28.

Delgado, C., Pardo, I., García, L., 2012. Diatom communities as indicators of ecological status in Mediterranean temporary streams (Balearic Islands, Spain). Ecol. Indic. 15, 131-139.

Ganesh Saratale, R., Kumar, G., Banu, R., Xia, A., Periyasamy, S., Dattatraya Saratale, G., 2018. A critical review on anaerobic digestion of microalgae and macroalgae and co-digestion of biomass for enhanced methane generation. Bioresour. Technol. 262, 319-332.
Gismondi, A., Pippo, F. Di, Bruno, L., Antonaroli, S., Congestri, R., 2016. Phosphorus removal coupled to bioenergy production by three cyanobacterial isolates in a biofilm dynamic growth system. Int. J. Phytoremed. 18, 869-876.

Gügi, B., Le Costaouec, T., Burel, C., Lerouge, P., Helbert, W., Bardor, M., Gügi, B., Le Costaouec, T., Burel, C., Lerouge, P., Helbert, W., Bardor, M., 2015. Diatom-specific oligosaccharide and polysaccharide structures help to unravel biosynthetic capabilities in diatoms. Mar. Drugs 13, 5993-6018.

Hasle, G.R., Fryxell, G.A., 1970. Diatoms: cleaning and mounting for light and electron microscopy. Trans. Am. Microsc. Soc. 89, 469.

Hildebrand, M., Davis, A.K., Smith, S.R., Traller, J.C., Abbriano, R., 2012. The place of diatoms in the biofuels industry. Biofuels 3, 221-240.

Hu, Q., Sommerfeld, M., Jarvis, E., Ghirardi, M., Posewitz, M., Seibert, M., Darzins, A., 2008. Microalgal triacylglycerols as feedstocks for biofuel production: perspectives and advances. Plant J. 54, 621-639.

Kangas, P., Mulbry, W., Klavon, P., Laughinghouse, H.D., Adey, W., 2017. High diversity within the periphyton community of an algal turf scrubber on the Susquehanna River. Ecol. Eng. 108, 564-572.

Kebede-Westhead, E., Pizarro, C., Mulbry, W.W., 2006. Treatment of swine manure effluent using freshwater algae: production, nutrient recovery, and elemental composition of algal biomass at four effluent loading rates. J. Appl. Phycol. 18, 41-46.

Komárek, J., Kaštovský, J., Mareš, J., Johansen, J.R., 2014. Taxonomic classification of cyanoprokaryotes (cyanobacterial genera) using a polyphasic approach. Preslia.

Krammer, K., Lange-Bertalot,H., 1991a. Bacillariophyceae. 3.Teil: Centrales, Fragilariaceae, Eunotiaceae. In Ettl, H., J.Gerloff, H. Heynig \& D. Mollenhauer (eds), Süsswasserflora von Mitteleuropa, Band 2/3. Gustav Fischer Verlag: Stuttgart,Jena, p. 576.

Li, Y., Chen, Y.-F., Chen, P., Min, M., Zhou, W., Martinez, B., Zhu, J., Ruan, R., 2011. Characterization of a microalga Chlorella sp. well adapted to highly concentrated municipal wastewater for nutrient removal and biodiesel production. Bioresour. Technol. 102, 5138-5144.

Li, X., Marella, T.K., Tao, L., Li, R., Tiwari, A., Li, G., 2017. Optimization of growth conditions and fatty acid analysis for three freshwater diatom isolates. Phycol. Res. 65, 177-187.

Lin, Q., Zhuo, W.-H., Wang, X.-W., Chen, C.-P., Gao, Y.-H., Liang, J.-R., 2018. Effects of fundamental nutrient stresses on the lipid accumulation profiles in two diatom species Thalassiosira weissflogii and Chaetoceros muelleri. Bioprocess Biosyst. Eng. 41, 1213-1224.

Liu, J., Vyverman, W., 2015. Differences in nutrient uptake capacity of the benthic filamentous algae Cladophora sp., Klebsormidium sp. and Pseudanabaena sp. under varying N/P conditions. Bioresour. Technol. 179, 234-242.

Moody, J.W., McGinty, C.M., Quinn, J.C., 2014. Global evaluation of biofuel potential from microalgae. Proc. Natl. Acad. Sci. U.S.A. 111, 8691-8696.

Mulbry, W., Kondrad, S., Buyer, J., 2008a. Treatment of dairy and swine manure effluents using freshwater algae: fatty acid content and composition of algal biomass at different manure loading rates. J. Appl. Phycol. 20, 1079-1085.

Mulbry, W., Kondrad, S., Pizarro, C., Kebede-Westhead, E., 2008b. Treatment of dairy manure effluent using freshwater algae: algal productivity and recovery of manure nutrients using pilot-scale algal turf scrubbers. Bioresour. Technol. 99, 8137-8142.

Mulbry, W.W., Kangas, P.C., Kondrad, S., 2010. Toward scrubbing the bay: nutrient removal using small algal turf scrubbers on Chesapeake Bay tributaries. Ecol. Eng. 36, 53.

Pandey, L.K., Han, T., Gaur, J.P., 2015. Response of a phytoplanktonic assemblage to copper and zinc enrichment in microcosm. Ecotoxicology 24, 573-582.

Pandey, L.K., Bergey, E.A., 2016a. Exploring the status of motility, lipid bodies, deformities and size reduction in periphytic diatom community from chronically metal $(\mathrm{Cu}, \mathrm{Zn})$ polluted waterbodies as a biomonitoring tool. Sci. Total Environ. 550, 372-381.

Pandey, L.K., Ojha, K.K., Singh, P.K., Singh, C.S., Dwivedi, S., Bergey, E.A., 2016. Diatoms image database of India (DIDI): a research tool. Environ. Technol. Innov. 5, 148-160.

Pate, R.C., 2013. Resource requirements for the large-scale production of algal biofuels. Biofuels 4, 409-435.

Pinto, T., Gouveia, L., Ortigueira, J., Saratale, G.D., Moura, P., 2018. Enhancement of fermentative hydrogen production from Spirogyra sp. by increased carbohydrate accumulation and selection of the biomass pretreatment under a biorefinery model. J. Biosci. Bioeng. 126, 226-234.

Schenk, P.M., Thomas-Hall, S.R., Stephens, E., Marx, U.C., Mussgnug, J.H., Posten, C., Kruse, O., Hankamer, B., 2008. Second generation biofuels: high-efficiency microalgae for biodiesel production. Bioenergy Res. 1, 20-43.

Schulze, P.S.C., Carvalho, C.F.M., Pereira, H., Varela, J.C.S., Barreira, L., 2017. Urban wastewater treatment by Tetraselmis sp. CTP4 (Chlorophyta). Bioresour. Technol. 223, 175-183.

Suman, K., Kiran, T., Devi, U.K., Sarma, N.S., 2012. Culture medium optimization and lipid profiling of Cylindrotheca, a lipid-and polyunsaturated fatty acid-rich pennate diatom and potential source of eicosapentaenoic acid. Bot. Mar. 55, 289-299.

Talebi, A.F., Mohtashami, S.K., Tabatabaei, M., Tohidfar, M., Bagheri, A., Zeinalabedini, M. Hadavand Mirzaei, H., Mirzajanzadeh, M., Malekzadeh Shafaroudi, S., Bakhtiari, S., 2013. Fatty acids profiling: a selective criterion for screening microalgae strains for biodiesel production. Algal Res. 2, 258-267.

Tamilarasan, K., Kavitha, S., Selvam, A., Rajesh Banu, J., Yeom, I.T., Nguyen, D.D., Saratale, G.D., 2018. Cost-effective, low thermo-chemo disperser pretreatment for biogas production potential of marine macroalgae Chaetomorpha antennina. Energy 163, 533-545.

Tilak, A.S., Wani, S.P., Datta, A., Patil, M.D., Kaushal, M., Reddy, K.R., 2017. Evaluation of Ageratum conyzoides in field scale constructed wetlands (CWs) for domestic wastewater treatment. Water Sci. Technol. 75, 2268-2280.

Úbeda, B., Gálvez, J.Á., Michel, M., Bartual, A., 2017. Microalgae cultivation in urban wastewater: Coelastrum cf. pseudomicroporum as a novel carotenoid source and a potential microalgae harvesting tool. Bioresour. Technol. 228, 210-217.

Williams, M., Kookana, R.S., Mehta, A., Yadav, S.K., Tailor, B.L., Maheshwari, B., 2019. Emerging contaminants in a river receiving untreated wastewater from an Indian urban centre. Sci. Total Environ. 647, 1256-1265. 